\title{
Distinct patterns of blood-stage parasite antigens detected by plasma lgG subclasses from individuals with different level of exposure to Plasmodium falciparum infections
}

Cathrine Holm Olesen ${ }^{2,9 \dagger}$, Karima Brahimi ${ }^{7 \dagger}$, Brian Vandahl2,9, Susana Lousada-Dietrich ${ }^{3}$, Prajakta S Jogdand ${ }^{3}$, Lasse S Vestergaard ${ }^{3,4}$, Daniel Dodoo ${ }^{5}$, Peter Højrup ${ }^{6}$, Michael Christiansen', Severin Olesen Larsen', Subhash Singh ${ }^{3,8^{*}}$, Michael Theisen ${ }^{1,3^{*}}$

\begin{abstract}
Background: In endemic regions naturally acquired immunity against Plasmodium falciparum develops as a function of age and exposure to parasite infections and is known to be mediated by lgG. The targets of protective antibodies remain to be fully defined. Several immunoepidemiological studies have indicated an association of cytophilic anti-parasite IgG with protection against malaria. It has been hypothesized that the initial antibody responses against parasite antigens upon first few Plasmodium falciparum infections is dominated by nonprotective IgG2/lgG4 and IgM antibodies, which then gradually develop into protective response dominated by cytophilic $\lg G 1$ and $\lg G 3$ antibodies.
\end{abstract}

Methods: Naturally occurring IgG antibodies against $P$. falciparum blood-stage antigens were analysed from plasma samples collected from four groups of individuals differing in age and level of exposure to $P$. falciparum infections. Western Blot profiling of blood-stage parasite antigens displaying reactivity with individual plasma samples in terms of their subclass specificities was conducted. Parasite antigens detected by $\lg G$ were grouped based on their apparent molecular sizes resolved by SDS-PAGE as high molecular weight ( $\geq 70 \mathrm{kDa}$ ) or low molecular weight (< $70 \mathrm{kDa}$ ). The number of discernable low molecular weight parasite antigens detected by different lgG subclass antibodies from each plasma sample was recorded. Using Wilcoxons rank sum test these reactivities were compared amongst groups of individuals with different levels of exposure to $P$. falciparum infections.

Results: IgG4 and IgM antibodies in plasma samples from all groups detected very few parasite antigens. IgG2 antibodies from all groups detected a common pattern of high molecular weight parasite antigens. Cytophilic lgG subclasses in plasma samples from individuals with higher levels of exposure to P. falciparum infections distinctly detected higher numbers of low molecular weight parasite antigens.

Conclusions: In the present study, there was no evidence for switching of antibody responses from non-cytophilic to cytophilic subclasses against blood-stage parasite antigens as a likely mechanism for induction of protective immunity against malaria.

\footnotetext{
* Correspondence: subhash@iiim.ac.in; mth@ssi.dk

† Contributed equally

'Department of Clinical Biochemistry, Statens Serum Institut, Copenhagen, Denmark

${ }^{3}$ Centre for Medical Parasitology at Department of International Health, Immunology and Microbiology, University of Copenhagen, Copenhagen, Denmark

Full list of author information is available at the end of the article
} 


\section{Background}

Immunoepidemiological studies have demonstrated that immunity against blood stage Plasmodium falciparum is associated with the acquisition of anti-parasite antibodies of the cytophilic subclasses [1], and in particular IgG3 [2-9]. No such protective association has been observed for non-cytophilic subclasses such as IgM and IgG4 $[2,3]$. For IgG2 conflicting evidence has been presented, associating levels of specific IgG2 antibodies with either an increased frequency of clinical malaria episodes $[1,2,10]$, or resistance to $P$. falciparum malaria $[11,12]$. It is noteworthy that protection against malaria by IgG2 has often been associated with the Fc $\gamma$ RIIaH131 allotype, a receptor point mutation which accords binding to IgG2 [11,13-16]. These observations support the importance of cytophilic antibodies in protection against malaria. It has been hypothesized that development of effective IgG-mediated anti-parasite immunity depends on the maturation of antibody responses, not only in terms of their antigen specificities and affinity maturation, but also in terms of class-switching implying that the progressive development of malaria immunity in older children can be attributed to a switch of anti-parasite antibodies from the non-cytophilic to the cytophilic subclasses $[3,17]$. It has even been proposed that the non-cytophilic antibodies could compete and block the protective mechanisms elicited through the binding of the cytophilic subclasses [17].

The subclass profile of naturally occurring IgG responses has therefore been extensively studied for several major blood-stage malaria vaccine candidate antigens. These analyses have mainly been carried out by ELISA using recombinant proteins or synthetic peptides usually representing subdomains of malarial proteins as test antigens. Such antigen preparations do not always accurately mimic native parasite protein conformations, including post-translational modifications. A more global approach was therefore adopted to study the targets of the naturally occurring anti-parasite IgG subclass responses through IgG subclass specific Western blot analysis of total parasite proteins expressed in mature blood stage schizonts. Purified Parasitophorous Vacuole Membrane-Enclosed Merozoite Structures (PEMS) [18] were used as a source for parasite antigens, because PEMS preparations i) contain a highly homogeneous synchronous parasite population at the mature schizont stage and ii) they are essentially free of contaminating host cell proteins.

Profiling of different naturally acquired IgG responses, in terms of their subclass specific recognition of parasite PEMS proteins, in individuals with different levels of exposure to $P$. falciparum infection is reported. Plasma samples were collected from four distinct sub-groups including: Group A: non-immune Danish travellers with a single episode of P. falciparum malaria; Group B: young (0-5 years) and Group C: older (6-10 years) Ghanaian children with frequent episodes of clinical malaria; and Group D: clinically immune Liberian adults. A group of non-immune Danish healthy adults (Group E) never exposed to malaria was included as control group.

\section{Methods}

\section{Parasite cultures and purification of PEMS}

Plasmodium falciparum (F32 strain) was cultured in vitro in human RBCs as previously described [19] using RPMI 1640 medium supplemented with 25 mM HEPES, $20 \mathrm{mM} \mathrm{NaHCO}, 2 \mathrm{mg} /$ liter hypoxanthine, $0.5 \%(\mathrm{w} / \mathrm{v})$ AlbuMAX I, and 1\% (v/v) penicillin-streptomycin at 5\% $\mathrm{v} / \mathrm{v}$ hematocrit. Cultures were synchronized by repeated treatment of parasites with D-sorbitol [20]. PEMS preparations were purified according to the protocol of Salmon et al [18]. Briefly, highly synchronized cultures at approx. $20 \%$ parasitemia were grown until the parasites had reached the schizont stage ( $>8$ nuclei stage), at which time they were treated with $10 \mu \mathrm{M}$ E64 (Sigma, Germany) for 8-10 h until the PEMS emerged. These PEMS were brought into suspension, incubated for another $2 \mathrm{~h}$ to allow for the vast majority of RBCs to sediment and then purified from the supernatant by centrifugation through $60 \% \mathrm{v} / \mathrm{v}$ Percoll. PEMS were collected from the top of the cushion, centrifuged for 10 min at $2000 \times \mathrm{g}$, washed three times in PBS containing protease inhibitor cocktail (Roche), and stored as packed cells at $-80^{\circ} \mathrm{C}$ until use. The quality and homogeneity of the purified PEMS were routinely evaluated by light microscopy of Giemsa-stained smears and by SDSPAGE. When adjusted for protein concentrations and under identical sample processing conditions, samples from different batches showed very similar protein patterns on Coomassie stained 1D-SDS-PAGE and silver stained 2-D gels (data not shown).

\section{Serum samples and ELISA}

Plasma samples from Liberian adults clinically immune to malaria $(\mathrm{n}=12)$, Danish donors never exposed to malaria $(\mathrm{n}=35)$, and Ghanian children $(\mathrm{n}=14)$ were selected randomly from previously published studies $[21,22]$. Plasma from non-immune Danish travelers $(\mathrm{n}=$ 7) were obtained from a routine diagnostic laboratory at SSI. These samples were from adults who i) had experienced a single attack of clinical $P$. falciparum malaria, and ii) had their malaria episode confirmed by a positive IFA test. Enzyme-linked immunosorbent assay (ELISA) was performed essentially as described [23] using an F32 late-stage schizont extract at a coating concentration of $50 \mu \mathrm{g} / \mathrm{ml}$. All plasma samples were tested at a dilution of 1:200 in PBS, pH 7.0. 


\section{SDS-PAGE and immunoblotting}

One dimensional SDS-polyacrylamide gel electrophoresis (PAGE) and immunoblotting was carried out as per standard procedures described earlier [24]. Membranes were incubated with individual plasma samples diluted 1:200 in PBS, $\mathrm{pH}$ 7.4. For IgG subclass detection, monoclonal mouse anti-human subclasses IgG1 to IgG4 (clones NL16, HP6002, Zg4, and RJ4 [Skybio]) were used as secondary antibodies in dilutions of 1:1000 followed by incubation with alkaline phosphatase (AP)conjugated rabbit anti-mouse IgG (Dako) at 1:1000.

\section{Statistical analysis}

The differences between the distributions of parasite antigen bands recognized by plasma IgG from different individuals were compared by calculating two-sides Pvalues based on Wilcoxons rank sum test with correction for ties. The differences between ELISA values were compared by the u-test.

\section{Results}

Levels of naturally acquired anti-parasite IgG vary amongst individuals with different levels of exposure to parasite infection

Levels of parasite-specific IgG antibodies were determined in plasma from four groups of individuals who differ in their level of exposure to malaria (Figure 1). Levels of parasite-specific IgG antibodies were similar in

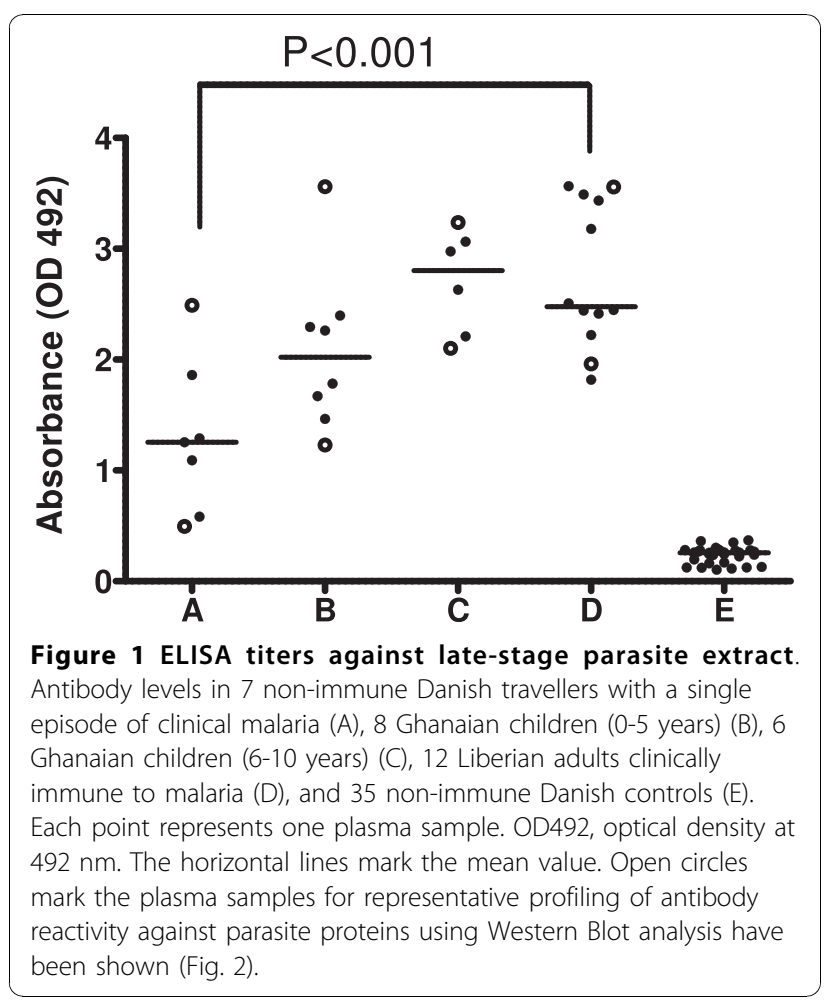

adult Liberians clinically immune to malaria and Ghanaian children in the age-groups 0-5 and 6-10, but were significantly higher than in non-immune Danish travellers (u-test, $\mathrm{P}<0.001$ ). This result is in agreement with the observation that the quantity of anti-parasite total IgG alone cannot explain naturally acquired immunity to P. falciparum asexual blood forms [17]. In order to further examine whether the IgG subclass distribution could play a role for the delayed acquisition of protective immunity, the parasite-specific IgG subclass profile in the above mentioned groups of individuals was characterized.

\section{Profiling of IgG subclass responses by immunoblot analysis of PEMS}

Purified PEMS preparation was used as a source of proteins expressed in mature schizonts. Microscopic examination of the PEMS preparation showed merozoite clusters surrounded by the PVM (data not shown). Proteins extracted from the PEMS preparation were separated by SDS-PAGE and subjected to immunoblot analysis.

Representative immunoblots displaying profiles of different antibody isotypes reactivity are shown in Figure 2. Both IgG4 and IgM isotypes were found to display weak and infrequent reactivity against parasite proteins in all groups. Amongst the remaining antibody isotypes, the IgG2 reactivity profile displayed a consistent pattern for nearly all plasma samples showing reactivity against a few high-molecular weight proteins with one protein of approximately $70-\mathrm{kDa}$ being particularly strongly recognized by the majority of samples (Group A, 2/7; Group B 5/7; Group C, 4/8; Group D, 12/12). In contrast, the IgG1 and IgG3 band profiles differed greatly between plasma samples from different exposure groups (Figure $2 \mathrm{~A}-\mathrm{D}$, lane 1 and 3). Another notable observation was the tendency for a broader IgG1 and IgG3 reactivity with increased exposure. As shown in Table 1, the number of IgG1 reactive bands below $70-\mathrm{kDa}$ was significantly greater in clinically immune Liberians compared to non-immune Danish travellers (Wilcoxons rank sum test, $\mathrm{P}=0.009$ ). The difference between groups was even more pronounced for the IgG3 reactivity with a significant difference between adult Liberians and young Ghanaian children (Wilcoxons rank sum test, $\mathrm{P}=0.006$ ) and non-immune Danish travellers (Wilcoxons rank sum test, $P=0.010)$. In general, Danish travellers with a single malaria episode reacted against a few high-molecular weight antigens, whereas those from Liberian adults recognized a larger number of both high- and low-molecular weight antigens (compare Figure $2 \mathrm{~A}$ and 2D and Table 1). Plasma samples from the Ghanaian children appeared to recognize an intermediate number of bands (Figure $2 \mathrm{~B}$ and $2 \mathrm{C}$ and Table 1). Thus, 


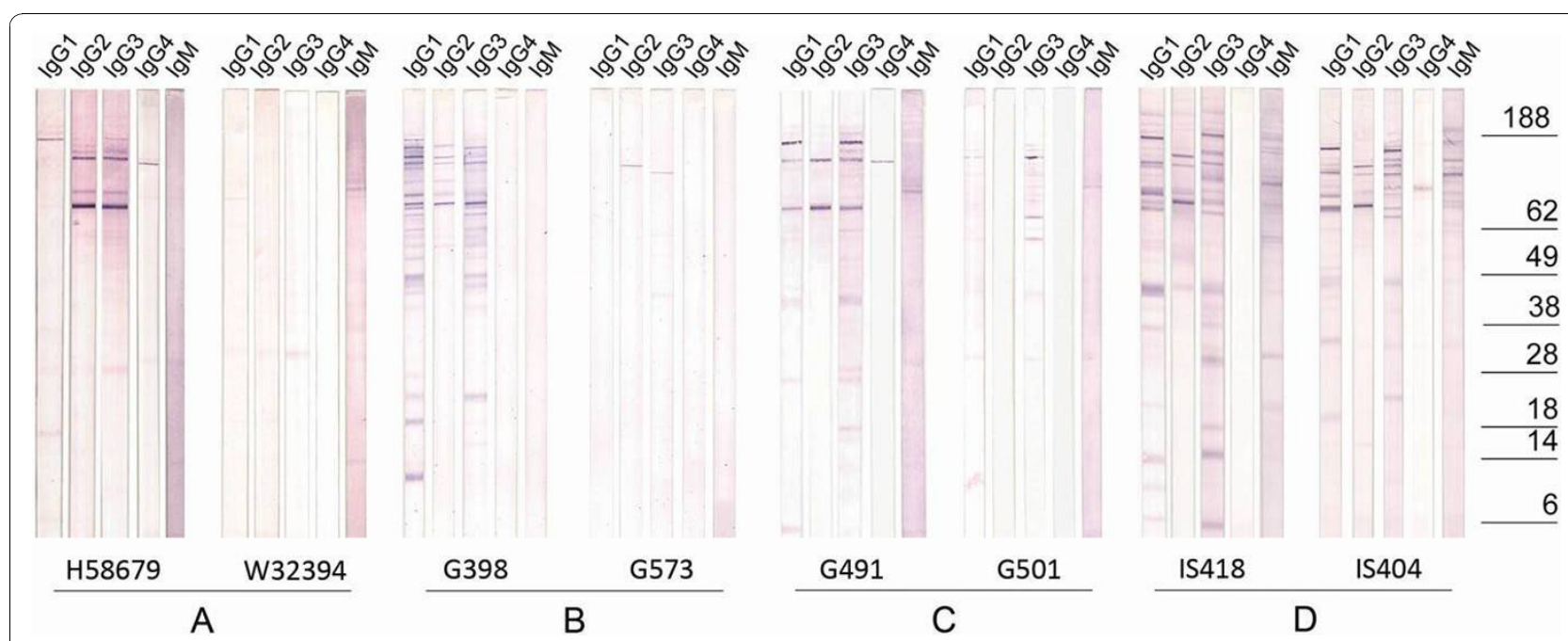

Figure 2 Western blot analysis of IgG subclass responses. Asexual blood-stage F32 parasite proteins (PEMS preparation, $100 \mu \mathrm{g}$ ) were separated by SDS-PAGE and blotted onto nitrocellulose membranes. Membranes were cut in vertical strips, blocked and incubated with individual plasma from A) Danish travelers who have suffered a single episode of $P$. falciparum malaria $(n=7)$, B) Ghanaian children age 0-5 ( $n=$ 8), C) Ghanaian children age 6-10 $(n=6)$, and D) clinically immune Liberian adults $(n=12)$. Antibody responses were revealed with monoclonal antibodies directed to human $\lg G 1, \lg G 2, \lg G 3, \lg G 4$ and $\lg M$ and visualized with AP-conjugated anti-mouse antibodies. For each of the different groups (A to D) reactivity of two representative individual plasma samples are shown, where the one to the left was seen to have high lgG titers determined by ELISA against late-stage parasite extract, whereas the one to the right had low lgG titers in the same assay. Western blots were performed with different SDS-PAGE gels, all loaded with the same protein preparation $(100 \mu \mathrm{g})$ and run under identical electrophoretic parameters. The strips shown originate from a single blot.

increased exposure to $P$. falciparum malaria resulted in increased antibody reactivity against wider range of lowmolecular weight parasite antigens.

\section{Discussion}

Naturally acquired immunity against malaria is highly prevalent in adults residing in malaria endemic regions. It is the strongest known resistance against severe clinical malaria, and it develops over a long period with repeated infections. Passive transfer of purified IgG from hyperimmune sera to malaria patients has demonstrated that IgG mediates anti-parasite activity and protection against malaria. However, the mechanisms involved in

Table 1 Differential immunoblot pattern of low-molecular weight $(<\mathbf{7 0} \mathrm{kDa})$ parasite antigens detected by cytophilic antibodies

\begin{tabular}{cccc}
\hline Groups & Composition & lgG1 $^{\text {Plasma samples }}$ & $\begin{array}{c}\text { Number of bands detected } \\
\text { (Median and interquartile } \\
\text { range) }\end{array}$ \\
\hline A & Adult Danish travelers & $5.0(4.0-6.0)^{\mathrm{c}}$ & $6.0(3.0-8.0)^{\mathrm{f}}$ \\
B & Ghanaian children (0-5 yr) & $5.5(2.0-8.0)^{\mathrm{b}}$ & $4.0(3.05 .0)^{\mathrm{e}}$ \\
C & Ghanaian children (6-10 yr) & $6.5(6.0-8.0)^{\mathrm{a}}$ & $8.5(4.5-13.5)^{\mathrm{d}}$ \\
D & Adult Liberians & $9.0(6.5-12.5)$ & $14(10.0-15.0)$ \\
\hline
\end{tabular}

Comparing lgG1 reactivity: ${ }^{a} D$ vs. $C, P=0.121$, D vs. $B^{b}, P=0.094$, and $D$ vs. $A^{c}, P=0.009$. Comparing lgG3 reactivity: ${ }^{d} D$ vs. $C, P=0.157, D$ vs. $B^{e}, P=$ 0.006 , and $D$ vs. $A^{f}, P=0.010$. P-values are based on Wilcoxons rank sum test with correction for ties. the acquisition of naturally acquired immunity and the targets of the protective IgG have not been completely elucidated. This report demonstrates a differential parasite antigen reactivity of IgG responses acquired against $P$. falciparum asexual blood stage antigens at different exposure levels with a particular focus on parasite antigens expressed in mature schizonts. Using parasite PEMS preparation as the source of antigens, antigenic profiling of the naturally acquired IgG has been carried out using ELISA and Western Blot analysis of parasite antigens separated by SDS PAGE. Conventionally, the approaches widely used to study host immune response against malaria antigens have relied on the use of recombinant proteins or synthetic peptides usually representing subdomains of parasite proteins which could differ from their corresponding native parasite counter-parts in terms of their overall structures and post-translational modifications both of which could potentially alter the antigenic property of the target protein. Since the selection of antigenic targets of interest has traditionally been the first step for studying naturally acquired immunity against malaria, very few studies have attempted an unbiased pan-profiling of antibody reactivity against a broad range of parasite antigens [25]. Alternatively, other studies have attempted to profile antibody reactivity against the whole parasite extract primarily through ELISA [23,26], an approach which does not yield information regarding the molecular 
characteristics of the specific antigens recognized by the sera samples. Recently, protein microarray approaches have been developed which enable antigenic analysis against wider range of antigens, but still this technique relies on use of recombinant proteins or synthetic peptides and may suffer from the above listed limitations [27-29]. The present approach of unbiased profiling of naturally acquired antibodies against parasite antigens using native parasite extract has obvious advantages over the use of recombinant proteins or synthetic peptides. As the Western blot method involves denaturing and reducing the antigens the responses reported here might preferentially be against denatured antigens, whereby reactivity against some antigens characterized by having three-dimensional epitopes could have been missed. However, a recent study on the antibody response against Schistosoma mansoni showed that the antigenic profiling was the same whether antigens had been denatured and reduced or not [30]. Other advantages of using proteins from the parasite extract over recombinant proteins or peptides would include covering all linear epitopes over the full-length protein together with all the post-translational modifications which could affect antigenic properties [31].

The analysis of total anti-parasite IgG in individuals subject to different levels of exposure revealed unexpectedly high levels of anti-parasite IgG in the Danish travellers' plasma after a single episode of clinical malaria. Though polyclonal activation of host B-cell response has been suggested to be mediated by certain parasite antigens [32], this does not appear to explain the profile of the primary attack IgG subclass specific reactivity observed in the Western blot analysis. Primary attack plasma samples showed selective and restricted reactivity against high molecular weight parasite antigens with IgG1, IgG2 and IgG3 responses, but very little IgG4 and IgM reactivity, indicating activation of selected B-cell clones rather than polyclonal activation. It is interesting to note that the pattern of IgG2 reactivity developed against high molecular weight antigens as a result of primary attack is also observed in plasma samples collected from Ghanaian children and Liberian hyperimmune individuals with multiple attacks. Additionally, increasing exposure leads to a broader repertoire of P. falciparum reactive IgGs with the highest number of antigens being recognized by plasma from clinically immune Liberian adults. A degree of antigenic influence on subclass specificity is particularly evident for the IgG1 and IgG3 subclasses, with some bands being recognized predominantly by IgG1 or IgG3 whilst others are recognized by both classes. In contrast, the IgG2 antibody response seems relatively independent of host age and exposure to $P$. falciparum. It appears that the antigens recognized by IgG2 are few and in most cases of high molecular weight (> $70 \mathrm{kDa})$. One antigen of approximately $70 \mathrm{kDa}$ was found to be particularly strongly recognized by majority of the plasma samples from all exposure groups. The apparently low prevalence of IgG2 antibodies to some malaria antigens is in agreement with many previous reports [6,33-35]. However, the observation that the IgG2 response in general seems independent of age and exposure is inconsistent with the prevailing hypothesis that the initial antibody response against $P$. falciparum is dominated by noncytophilic antibodies (IgG2/IgG4 and IgM), and that this response gradually develops into a more protective response dominated by cytophilic IgG1 and IgG3 antibodies [17]. The data presented here suggests that the anti- $P$. falciparum IgG2 response is directed against a few high-molecular weight antigens and that the agedependent IgG1 and/or IgG3 responses observed against several low-molecular weight proteins are not preceded by corresponding IgG2 responses.

This observation suggests that clonal B-cell activation is age and exposure dependent. It seems that upon subsequent malaria attacks, additional B-cell clones are activated, which primarily generate IgG1/IgG3 responses and which may contribute to the gradual development of immunity. The immune response to a wide range of antigens is weak upon the first few exposures to malaria infections. It is likely that the parasite may produce immune-suppressive factors [36-38] resulting in poor immunogenicity of at least some malaria antigens. However, upon repeated exposures to malaria infection a widened range of parasite antigens react with the developed antibodies. It is hypothesized that a first step towards developing IgG reactivity to wide range of parasite antigens and thus clinical protection would be to develop effective neutralizing factors towards such parasite encoded immune suppressive factors. This could happen in combination with age dependent physiological changes [39].

Results from this study suggest that the progressive development of anti-parasite immunity in older children is not mediated by a general switch of malaria-specific antibodies from the non-cytophilic to the cytophilic subclasses. Taken together, the data suggests that the long time required to acquire clinical protection against $P$. falciparum malaria is not only related to isotype switching towards ADCI-effective antigens but also to a gradual development of IgG1 and IgG3 antibodies against some previously non-targeted antigens like the distinct low-molecular weight $P$. falciparum proteins detected in this study.

\section{Conclusion}

The present study confirms and extends previous observations suggesting that the cytophilic anti-P. falciparum 
IgG subclass responses increase with age and exposure, however, subclass switching from pre-existing non-cytophilic antibody responses to cytophilic subclass may not be a general phenomenon.

\section{Acknowledgements}

We thank M. Paulli Andersen for technical assistance.

\author{
Author details \\ 'Department of Clinical Biochemistry, Statens Serum Institut, Copenhagen, \\ Denmark. ${ }^{2}$ Department of Immunology, Infectious Disease Immunology, \\ Statens Serum Institut, Copenhagen, Denmark. ${ }^{3}$ Centre for Medical \\ Parasitology at Department of International Health, Immunology and \\ Microbiology, University of Copenhagen, Copenhagen, Denmark. \\ ${ }^{4}$ Parasitology Laboratory at the Department of Bacteriology, Mycology and \\ Parasitology, Statens Serum Institut, Copenhagen, Denmark. ${ }^{5}$ Noguchi \\ Memorial Institute for Medical Research, University of Ghana, Legon, Ghana. \\ ${ }^{6}$ Department of Biochemistry and Molecular Biology, University of Southern \\ Denmark, Denmark. ${ }^{7}$ Bio-Medical Parasitology Unit, Pasteur Institute, Paris, \\ France. ${ }^{8}$ Indian Institute of Integrative Medicine, Jammu, India. ${ }^{9}$ Novo \\ Nordisk A/S, 2820 Gentofte, Denmark.
}

\section{Authors' contributions}

BV, SS and MT conceived the study. CHO, KB, SLD, PSJ, LSV, DD, PH, MC, SOL and SS performed the laboratory work and the statistical analysis. SS and MT wrote the manuscript. All authors have read the manuscript and agree with its contents.

\section{Competing interests}

The authors declare that they have no competing interests

Received: 11 May 2010 Accepted: 26 October 2010

Published: 26 October 2010

\section{References}

1. Ndungu FM, Bull PC, Ross A, Lowe BS, Kabiru E, Marsh K: Naturally acquired immunoglobulin (Ig)G subclass antibodies to crude asexual Plasmodium falciparum lysates: evidence for association with protection for IgG1 and disease for IgG2. Parasite Immunol 2002, 24:77-82.

2. Chumpitazi BF, Lepers JP, Simon J, Deloron P: IgG1 and IgG2 antibody responses to Plasmodium falciparum exoantigens correlate inversely and positively, respectively, to the number of malaria attacks. FEMS Immunol Med Microbiol 1996, 14:151-158.

3. Luty AJ, Mayombo J, Lekoulou F, Mshana R: Immunologic responses to soluble exoantigens of Plasmodium falciparum in Gabonese children exposed to continuous intense infection. Am J Trop Med Hyg 1994, 51:720-729.

4. Sarthou JL, Angel G, Aribot G, Rogier C, Dieye A, Toure Balde A, Diatta B, Seignot P, Roussilhon C: Prognostic value of anti-Plasmodium falciparumspecific immunoglobulin $\mathrm{G} 3$, cytokines, and their soluble receptors in West African patients with severe malaria. Infect Immun 1997, 65:3271-3276.

5. Shi YP, Sayed U, Qari SH, Roberts JM, Udhayakumar V, Oloo AJ, Hawley WA, Kaslow DC, Nahlen BL, Lal AA: Natural immune response to the Cterminal 19-kilodalton domain of Plasmodium falciparum merozoite surface protein 1. Infect Immun 1996, 64:2716-2723.

6. Taylor RR, Allen SJ, Greenwood BM, Riley EM: IgG3 antibodies to Plasmodium falciparum merozoite surface protein 2 (MSP2): increasing prevalence with age and association with clinical immunity to malaria. Am J Trop Med Hyg 1998, 58:406-413.

7. Iriemenam NC, Khirelsied AH, Nasr A, EIGhazali G, Giha HA, Elhassan AETM, Agab-Aldour AA, Montgomery SM, Anders RF, Theisen M, TroyeBlomberg M, Elbashir MI, Berzins K: Antibody responses to a panel of Plasmodium falciparum malaria blood-stage antigens in relation to clinical disease outcome in Sudan. Vaccine 2009, 27:62-71.

8. Nebie I, Diarra A, Ouedraogo A, Soulama I, Bougouma EC, Tiono AB, Konate AT, Chilengi R, Theisen M, Dodoo D, Remarque E, Bosomprah S, Milligan P, Sirima SB: Humoral responses to Plasmodium falciparum blood-stage antigens and association with incidence of clinical malaria in children living in an area of seasonal malaria transmission in Burkina Faso, West Africa. Infect Immun 2008, 76:759-766.

9. Roussilhon C, Oeuvray C, Muller-Graf C, Tall A, Rogier C, Trape JF, Theisen M, Balde A, Perignon JL, Druilhe P: Long-term clinical protection from falciparum malaria is strongly associated with $\lg \mathrm{G} 3$ antibodies to merozoite surface protein 3. PLoS Med 2007, 4:e320.

10. Schreiber N, Brattig N, Evans J, Tsiri A, Horstmann RD, May J, Klinkert MQ: Cerebral malaria is associated with $\lg \mathrm{G} 2$ and $\lg G 4$ antibody responses to recombinant Plasmodium falciparum RIFIN antigen. Microbes Infect 2006, 8:1269-1276.

11. Aucan C, Traore Y, Tall F, Nacro B, Traore-Leroux T, Fumoux F, Rihet P: High immunoglobulin $\mathrm{G} 2$ (lgG2) and low lgG4 levels are associated with human resistance to Plasmodium falciparum malaria. Infect Immun 2000, 68:1252-1258.

12. Oeuvray C, Theisen M, Rogier C, Trape JF, Jepsen S, Druilhe P: Cytophilic immunoglobulin responses to Plasmodium falciparum glutamate-rich protein are correlated with protection against clinical malaria in Dielmo, Senegal. Infect Immun 2000, 68:2617-2620.

13. Nasr A, Iriemenam NC, Troye-Blomberg M, Giha HA, Balogun HA, Osman OF, Montgomery SM, ElGhazali G, Berzins K: Fc gamma receptor lla (CD32) polymorphism and antibody responses to asexual blood-stage antigens of Plasmodium falciparum malaria in Sudanese patients. Scand $J$ Immunol 2007, 66:87-96.

14. Shi YP, Nahlen BL, Kariuki S, Urdahl KB, McElroy PD, Roberts JM, Lal AA: Fc Receptor Ila (CD32) polymorphism is associated with protection of infants against high-density Plasmodium falciparum infection. VII. Asembo Bay Cohort Project. J Infect Dis 2001, 184:107-111.

15. Leoratti FM, Durlacher RR, Lacerda MV, Alecrim MG, Ferreira AW, Sanchez MC, Moraes SL: Pattern of humoral immune response to Plasmodium falciparum blood stages in individuals presenting different clinical expressions of malaria. Malar J 2008, 7:186.

16. Sinha S, Mishra SK, Sharma S, Patibandla PK, Mallick PK, Sharma SK, Mohanty S, Pati SS, Ramteke BK, Bhatt R, Joshi H, Dash AP, Ahuja RC, Awasthi S, Venkatesh V, Habib S: Polymorphisms of TNF-enhancer and gene for FcgammaRlla correlate with the severity of falciparum malaria in the ethnically diverse Indian population. Malar J 2008, 7:13.

17. Bouharoun-Tayoun H, Druilhe P: Plasmodium falciparum malaria: evidence for an isotype imbalance which may be responsible for delayed acquisition of protective immunity. Infect Immun 1992, 60:1473-1481.

18. Salmon BL, Oksman A, Goldberg DE: Malaria parasite exit from the host erythrocyte: a two-step process requiring extraerythrocytic proteolysis. Proc Natl Acad Sci USA 2001, 98:271-276.

19. Jepsen S, Andersen BJ: Immunoadsorbent isolation of antigens from the culture medium of in vitro cultivated Plasmodium falciparum. Acta Pathol Microbiol Scand C 1981, 89:99-103.

20. Lambros C, Vanderberg JP: Synchronization of Plasmodium falciparum erythrocytic stages in culture. J Parasitol 1979, 65:418-420

21. Theisen M, Soe $S$, Jessing $S$, Okkels L, Danielsen $S$, Oeuvray $C$, Druilhe $P$, Jepsen S: Identification of a major linear B cell epitope of the Plasmodium falciparum Glutamate-rich protein (GLURP), targeted by human antibodies mediating parasite killing. Vaccine 2000, 19:204-212

22. Dodoo D, Aikins A, Kusi KA, Lamptey $H$, Remarque E, Milligan $P$, Bosomprah S, Chilengi R, Osei YD, Akanmori BD, Theisen M: Cohort study of the association of antibody levels to AMA1, MSP119, MSP3 and GLURP with protection from clinical malaria in Ghanaian children. Malar J 2008, 7:142.

23. Okech B, Mujuzi G, Ogwal A, Shirai H, Horii T, Egwang TG: High titers of IgG antibodies against Plasmodium falciparum serine repeat antigen 5 (SERA5) are associated with protection against severe malaria in Ugandan children. Am J Trop Med Hyg 2006, 74:191-197.

24. Theisen M, Frederiksen B, Lebech AM, Vuust J, Hansen K: Polymorphism in $\operatorname{ospC}$ gene of Borrelia burgdorferi and immunoreactivity of OspC protein: implications for taxonomy and for use of OspC protein as a diagnostic antigen. J Clin Microbiol 1993, 31:2570-2576.

25. Thelu J, Sheick-Zakiuddin I, Boudin C, Peyron F, Picot S, AmbroiseThomas P: Development of natural immunity in Plasmodium falciparum malaria: study of antibody response by Western immunoblotting. J Clin Microbiol 1991, 29:510-518.

26. Aribot G, Rogier C, Sarthou JL, Trape JF, Balde AT, Druilhe P, Roussilhon C: Pattern of immunoglobulin isotype response to Plasmodium falciparum 
blood-stage antigens in individuals living in a holoendemic area of Senegal (Dielmo, west Africa). Am J Trop Med Hyg 1996, 54:449-457.

27. Doolan DL, Mu Y, Unal B, Sundaresh S, Hirst S, Valdez C, Randall A, Molina D, Liang X, Freilich DA, Oloo JA, Blair PL, Aguiar JC, Baldi P, Davies DH, Felgner PL: Profiling humoral immune responses to $P$. falciparum infection with protein microarrays. Proteomics 2008, 8:4680-4694.

28. Gray JC, Corran PH, Mangia E, Gaunt MW, Li Q, Tetteh KK, Polley SD, Conway DJ, Holder AA, Bacarese-Hamilton T, Riley EM, Crisanti A: Profiling the antibody immune response against blood stage malaria vaccine candidates. Clin Chem 2007, 53:1244-1253.

29. Crompton PD, Kayala MA, Traore B, Kayentao K, Ongoiba A, Weiss GE, Molina DM, Burk CR, Waisberg M, Jasinskas A, Tan X, Doumbo S, Doumtabe D, Kone Y, Narum DL, Liang X, Doumbo OK, Miller LH, Doolan DL, Baldi P, Felgner PL, Pierce SK: A prospective analysis of the Ab response to Plasmodium falciparum before and after a malaria season by protein microarray. Proc Natl Acad Sci USA 2010, 107:6958-6963.

30. El Ridi R, Tallima H, Mohamed SH, Montash M: Depletion of Schistosoma mansoni lung-stage schistosomula cholesterol by methyl-betacyclodextrin dramatically increases specific antibody binding to surface membrane antigens. J Parasitol 2004, 90:727-732.

31. Chung DW, Ponts N, Cervantes S, Le Roch KG: Post-translational modifications in Plasmodium: more than you think! Mol Biochem Parasitol 2009, 168:123-134.

32. Donati D, Zhang LP, Chene A, Chen Q, Flick K, Nystrom M, Wahlgren M, Bejarano MT: Identification of a polyclonal B-cell activator in Plasmodium falciparum. Infect Immun 2004, 72:5412-5418.

33. Egan AF, Chappel JA, Burghaus PA, Morris JS, McBride JS, Holder AA, Kaslow DC, Riley EM: Serum antibodies from malaria-exposed people recognize conserved epitopes formed by the two epidermal growth factor motifs of MSP1(19), the carboxy-terminal fragment of the major merozoite surface protein of Plasmodium falciparum. Infect Immun 1995, 63:456-466.

34. Tongren JE, Drakeley CJ, McDonald SL, Reyburn HG, Manjurano A, Nkya WM, Lemnge MM, Gowda CD, Todd JE, Corran PH, Riley EM: Target antigen, age, and duration of antigen exposure independently regulate immunoglobulin G subclass switching in malaria. Infect Immun 2006, 74:257-264.

35. Stanisic DI, Richards JS, McCallum FJ, Michon P, King CL, Schoepflin S, Gilson PR, Murphy VJ, Anders RF, Mueller I, Beeson JG: Immunoglobulin G subclass-specific responses against Plasmodium falciparum merozoite antigens are associated with control of parasitemia and protection from symptomatic illness. Infect Immun 2009, 77:1165-1174.

36. Roestenberg M, McCall M, Hopman J, Wiersma J, Luty AJ, van Gemert GJ, van de Vegte-Bolmer M, van Schaijk B, Teelen $K$, Arens T, Spaarman $L$, de Mast Q, Roeffen W, Snounou G, Renia L, van der Ven A, Hermsen CC, Sauerwein $R$ : Protection against a malaria challenge by sporozoite inoculation. N Engl J Med 2009, 361:468-477.

37. Singh $M$, Mukherjee $P$, Narayanasamy $K$, Arora $R$, Sen SD, Gupta $S$, Natarajan K, Malhotra P: Proteome analysis of Plasmodium falciparum extracellular secretory antigens at asexual blood stages reveals a cohort of proteins with possible roles in immune modulation and signaling. $\mathrm{Mol}$ Cell Proteomics 2009, 8:2102-2118.

38. Bejon P, Mwacharo J, Kai O, Todryk S, Keating S, Lowe B, Lang T, Mwangi TW, Gilbert SC, Peshu N, Marsh K, Hill AV: The induction and persistence of T cell IFN-gamma responses after vaccination or natural exposure is suppressed by Plasmodium falciparum. J Immunol 2007, 179:4193-4201.

39. Kurtis JD, Mtalib R, Onyango FK, Duffy PE: Human resistance to Plasmodium falciparum increases during puberty and is predicted by dehydroepiandrosterone sulfate levels. Infect Immun 2001, 69:123-128.

doi:10.1186/1475-2875-9-296

Cite this article as: Olesen et al:: Distinct patterns of blood-stage parasite antigens detected by plasma IgG subclasses from individuals with different level of exposure to Plasmodium falciparum infections. Malaria Journal 2010 9:296.

\section{Submit your next manuscript to BioMed Central and take full advantage of:}

- Convenient online submission

- Thorough peer review

- No space constraints or color figure charges

- Immediate publication on acceptance

- Inclusion in PubMed, CAS, Scopus and Google Scholar

- Research which is freely available for redistribution

Submit your manuscript at www.biomedcentral.com/submit
Biomed Central 